\title{
Novel triple-positive markers identified in human non-small cell lung cancer cell line with chemotherapy-resistant and putative cancer stem cell characteristics
}

\author{
NAZILAH ABDUL SATAR ${ }^{1 *}$, KAMAL SHAIK FAKIRUDDIN ${ }^{2,5^{*}}$, MOON NIAN LIM $^{2}$, POOI LING MOK ${ }^{3,4,6}$, \\ NORASHIKIN ZAKARIA ${ }^{1}$, NOOR ATIQAH FAKHARUZI ${ }^{2}$, AHMAD ZUHAIRI ABD RAHMAN $^{2}$, \\ ZUBAIDAH ZAKARIA $^{2}$, BADRUL HISHAM YAHAYA ${ }^{1}$ and PUTERI BAHARUDDIN ${ }^{2}$
}

\begin{abstract}
${ }^{1}$ Regenerative Medicine Cluster, Advanced Medical and Dental Institute (AMDI), Universiti Sains Malaysia, 13200 Penang; ${ }^{2}$ Stem Cell Laboratory, Haematology Unit, Cancer Research Centre, Institute for Medical Research (IMR), 50588 Kuala Lumpur; ${ }^{3}$ Department of Biomedical Science, Faculty of Medicine and Health Sciences, Universiti Putra Malaysia, 43400 UPM Serdang, Selangor; ${ }^{4}$ Genetics and Regenerative Medicine Research Centre, Faculty of Medicine and Health Sciences, Universiti Putra Malaysia, 43400 UPM Serdang, Selangor; ${ }^{5}$ Institute of Bioscience, Universiti Putra Malaysia, 43400 UPM Serdang, Selangor, Malaysia; ${ }^{6}$ Department of Clinical Laboratory Sciences, College of Applied Medical Sciences, Jouf University, Sakaka, Aljouf, Kingdom of Saudi Arabia
\end{abstract}

Received October 17, 2017; Accepted April 3, 2018

DOI: 10.3892/or.2018.6461

\begin{abstract}
Through the specific identification and direct targeting of cancer stem cells (CSCs), it is believed that a better treatment efficacy of cancer may be achieved.Hence, the present study aimed to identify a CSC subpopulation from adenocarcinoma cells (A549) as a model of non-small cell lung cancer (NSCLC). Initially, we sorted two subpopulations known as the triple-positive $\left(\mathrm{EpCAM}^{+} / \mathrm{CD} 166^{+} / \mathrm{CD} 44^{+}\right)$and triple-negative (EpCAM $\left.{ }^{-} / \mathrm{CD} 166^{\circ} / \mathrm{CD} 44^{-}\right)$subpopulation using fluorescenceactivated cell sorting (FACS). Sorted cells were subsequently evaluated for proliferation and chemotherapy-resistance using a viability assay and were further characterized for their clonal heterogeneity, self-renewal characteristics, cellular migration, alkaline dehydrogenase (ALDH) activity and the expression of stemness-related genes. According to our findings the triple-positive subpopulation revealed significantly higher $(\mathrm{P}<0.01)$ proliferation activity, exhibited better clonogenicity, was mostly comprised of holoclones and had markedly bigger $(\mathrm{P}<0.001)$ spheroid formation indicating a better self-renewal capacity. A relatively higher resistance to both 5-fluouracil and cisplatin with $80 \%$ expression of ALDH was observed in the triple-positive subpopulation, compared to only $67 \%$
\end{abstract}

Correspondence to: Mr. Kamal Shaik Fakiruddin, Stem Cell Laboratory, Haematology Unit, Cancer Research Centre, Institute for Medical Research, Jalan Pahang, 50588 Kuala Lumpur, Malaysia E-mail:kamal@imr.gov.my

*Contributed equally

Key words: CSCs, triple-positive markers, $\mathrm{EpCAM}^{+} / \mathrm{CD} 166^{+} /$ CD $44^{+}$cells, A549 cell line, NSCLC detected in the triple-negative subpopulation indicated that high ALDH activity contributed to greater chemotherapyresistance characteristics. Higher percentage of migrated cells was observed in the triple-positive subpopulation with $56 \%$ cellular migration being detected, compared to only $19 \%$ in the triple-negative subpopulation on day 2 . This was similarly observed on day 3 in the triple-positive subpopulation with $36 \%$ higher cellular migration compared to the triple-negative subpopulation. Consistently, elevated levels of the stem cell genes such as REXI and SSEA4 were also found in the triple-positive subpopulation indicating that the subpopulation displayed a strong characteristic of pluripotency. In conclusion, our study revealed that the triple-positive subpopulation demonstrated similar characteristics to CSCs compared to the triple-negative subpopulation. It also confirmed the feasibility of using the triple-positive $\left(\mathrm{EpCAM}^{+} / \mathrm{CD} 166^{+} / \mathrm{CD} 44^{+}\right)$marker as a novel candidate marker that may lead to the development of novel therapies targeting CSCs of NSCLC.

\section{Introduction}

Non-small cell lung cancer (NSCLC) is the most common type of lung cancer in the world, which accounts for approximately $80-85 \%$ of all lung cancer cases while the remaining $20 \%$ is attributed to small-cell lung cancer (1-3). NSCLC is generally resistant to chemotherapy and radiation, which often leads to relapse and even mortality after the initial treatment (4-6). Growing evidence has supported the role of cancer stem cells (CSCs) in the expansion, progression and chemoresistance of tumour cells, including those of lung cancer (7). Current therapies of NSCLC are less likely to affect CSCs, due to the characteristics of these cells or their subpopulations that are intrinsically less sensitive to common treatments (8-10). In addition, CSCs are largely quiescent to treatments, which 
allows them to elude standard chemotherapies. Therefore, failure to eradicate these subpopulations are the underlying cause of cancer relapse and fatality $(11,12)$. The effort to identify new markers of lung tumour CSCs that can predict tumour progression through early stage diagnosis is an effective approach, since late detection may significantly lead to higher metastasis and mortality (13). Furthermore, the development of cancer as well as tumour cell metastasis is believed to be driven by CSCs, which has been supported by many studies $(14,15)$. Therefore, in order to increase the efficacy of treatment and detection of the disease, several CSC markers have been identified. Although, many of these markers do exist in the context of lung cancer, nevertheless we believe that a precise characterization of the cells isolated by these markers, specifically for NSCLC is still needed.

Several CSC markers have been identified from various tumours including malignant cells derived from breast (16), pancreas (17) prostate (18), colon (19) and head and neck (20) cancer, as well as leukaemia (21). Concerning lung cancer, putative CSCs derived from various surface markers including CD24 (22), CD133 (23), CD44 (24), CD166 (25) and CD326 (EpCAM) (26) have also been extensively studied and characterised. An example is the epithelial cell adhesion molecule known as the EpCAM, mostly expressed in several human carcinomas and in the majority of normal epithelial cells (27). Due to the strong association between the high expression of EpCAM and the progression of tumour cells in NSCLC, it is believed that this molecule would serve as a prominent marker that can distinguish CSCs from non-CSCs in tumour specimens which are mostly consisted of squamous cell carcinoma (28-30). In addition, EpCAM was observed to be an important biomarker due to its ability to detect circulating tumour cells in the blood of lung cancer patients (31). Another example is the leukocyte cell adhesion molecule (ALCAM) or CD166 that was also found to be a robust marker of lung CSCs, based on the high expression detected in most lung cancer samples and the capacity of the isolated cells to exhibit self-renewal capacity and differentiation in vivo (32). The chemotherapy-resistant characteristic is also one of the hallmarks that can specifically discriminate a CSC from a non-CSC subpopulation. For instance, a specific tumour subpopulation isolated from breast (33), colon (34) and gastric (35) cancer is believed to be a CSC subpopulation based on the expression of the homing cell adhesion molecule (HCAM) or CD44. The isolated cells positive for CD44 possess the ability for self-renewal and also the characteristic of being resistant to common chemotherapy, indicating the utility of CD44 as a marker for CSC (35). Furthermore, CD44 was also believed to be crucial for initiating and driving NSCLC stem cell mobility and metastasis (36). Hence, the aim of the present study was to identify and characterise a novel CSC subpopulation from the A549 cell line used as a model of NSCLC using a novel combination of three markers, EpCAM, CD166 and CD44, rather than single markers to strengthen the selection of the CSC population.

\section{Materials and methods}

Cell culture of NSCLC cell line (A549). The human NSCLC cell line A549, was obtained from the American Type Culture
Collection (ATCC; Manassas, VA, USA). Cells were grown and maintained in a complete RPMI-1640 medium (Invitrogen, Carlsbad, CA, USA) containing $10 \%$ foetal bovine serum (FBS), $100 \mathrm{IU} / \mathrm{ml}$ penicillin and $100 \mu \mathrm{g} / \mathrm{ml}$ streptomycin and were grown at $37^{\circ} \mathrm{C}$ in a humidified atmosphere of $5 \% \mathrm{CO}_{2}$. The cells were maintained in a $75-\mathrm{cm}^{2}$ tissue cultured flask and were harvested using $0.25 \%$ trypsin-EDTA. All culture reagents were obtained from Gibco (Thermo Fisher Scientific, Inc., Waltham, MA, USA) unless otherwise stated.

Sorting of triple-positive (EpCAM $\left.{ }^{+} / C D 166^{+} / C D 44^{+}\right)$and triple-negative (EpCAM-/CD166\%/CD44-) subpopulations. The A549 cells were harvested by incubating the cells with $0.25 \%$ trypsin and followed by washing with phosphate-buffered solution (PBS) containing 2\% FBS. The suspension cells were then labelled with antibodies (CD326/ EpCAM-APC; 1:10 dilutions; cat. no. 347200; CD166-PE; 1:10 dilutions; cat. no. 560903; and CD44-FITC; 1:10 dilutions; cat. no. 347943) (BD Biosciences, San Jose, CA, USA). Briefly, the cells were transferred into $75-\mathrm{mm}$ polystyrene round bottom test tubes (BD Falcon; BD Biosciences) and were suspended in PBS (90 $\mu \mathrm{l})$ added with $2 \%$ FBS at a concentration of $1 \times 10^{6}$ cells $/ \mathrm{ml}$. Subsequently, $10 \mu \mathrm{l}$ of each antibody were added into the cell suspension and were subsequently incubated for $30 \mathrm{~min}$ in the dark. The cells were then washed and filtered through a $40-\mu \mathrm{m}$ cell strainer to obtain a single cell suspension before sorting. The expression of the CSC markers, EpCAM, CD166 and CD44 was analysed and sorted using a Fluorescence Activated Cell Sorter (FACSAria III; BD Biosciences). Gating was used for sorting out triple-positive $\left(\mathrm{EpCAM}^{+} / \mathrm{CD} 166^{+} / \mathrm{CD} 44^{+}\right)$and triple-negative (EpCAM ${ }^{-}$ CD166\%/CD44 ${ }^{-}$) population (Fig. 1).

Cell proliferation assay. MTS assay [3-(4, 5-dimethylthiazol2-yl)-2H-tetrazolium, inner salt] was purchased from Promega (Madison, WI, USA) and was used to quantify the proliferation of both sorted and unsorted A549 cells at different time-points (24, 48 and $72 \mathrm{~h}$ ). The cells were seeded at a density of $1 \times 10^{4}$ cells/well in a 96-well plate and were incubated for the appropriate length of time $(24,48$ and $72 \mathrm{~h})$ in a humidified $5 \% \mathrm{CO}_{2}$ incubator at $37^{\circ} \mathrm{C}$. Following that, the MTS solution $(15 \mu \mathrm{l})$ was added to each individual well for further incubation for $4 \mathrm{~h}$. Subsequently, solubilisation solution (100 $\mu \mathrm{l})$ was added to the cells and absorbance was assessed using Odyssey ${ }^{\circledR}$ Sa Imaging system (LI-COR Biosciences, Lincoln, NE, USA) at $570 \mathrm{~nm}$, using wells without cells as blank. The viability of cells at different time-points was calculated according to the following formula: cell viability $(\%)=$ cells $($ sample $) /$ cells (control) x 100 .

Clonogenic assay. Both sorted [triple-positive (EpCAM ${ }^{+}$ $\mathrm{CD} 166^{+} / \mathrm{CD}^{4} 4^{+}$) and triple-negative (EpCAM-CD166 $\left./ \mathrm{CD}^{-} 4^{-}\right)$] and unsorted A549 cells were seeded in triplicates $(1,000$ cells $/ \mathrm{ml})$ into a 6-well plate containing $2 \mathrm{ml}$ of complete RPMI-1640 medium per well. The sorted cells were kept in a culture at $37^{\circ} \mathrm{C}$ in a $5 \% \mathrm{CO}_{2}$ humidified incubator for 14 days. After 14 days, the colonies were observed using an inverted microscope (Olympus, Tokyo, Japan) at x200 magnification and images from 20 fields of view were captured to evaluate, characterise and manually count the different clones, namely, holoclones, 
A

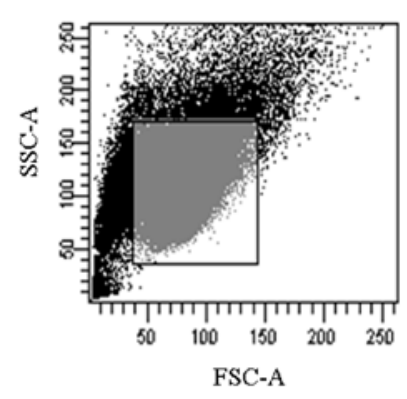

All events (EpCAM/CD166/CD44)
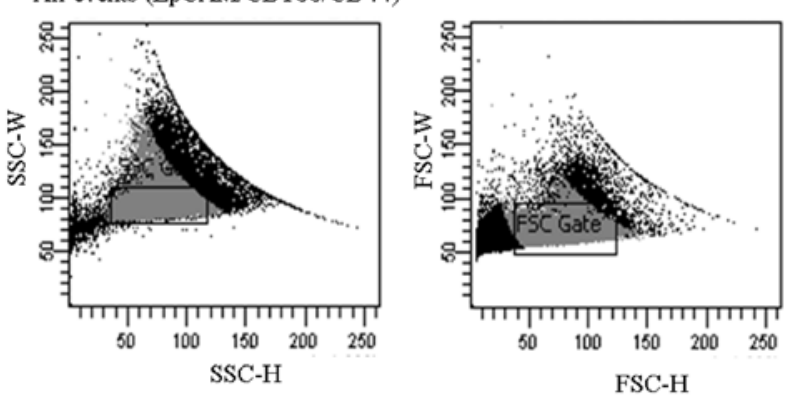

B

$\mathrm{Pl}: \mathrm{EpCAM}^{+} / \mathrm{CD} 66^{+} / \mathrm{CD} 44^{+}$
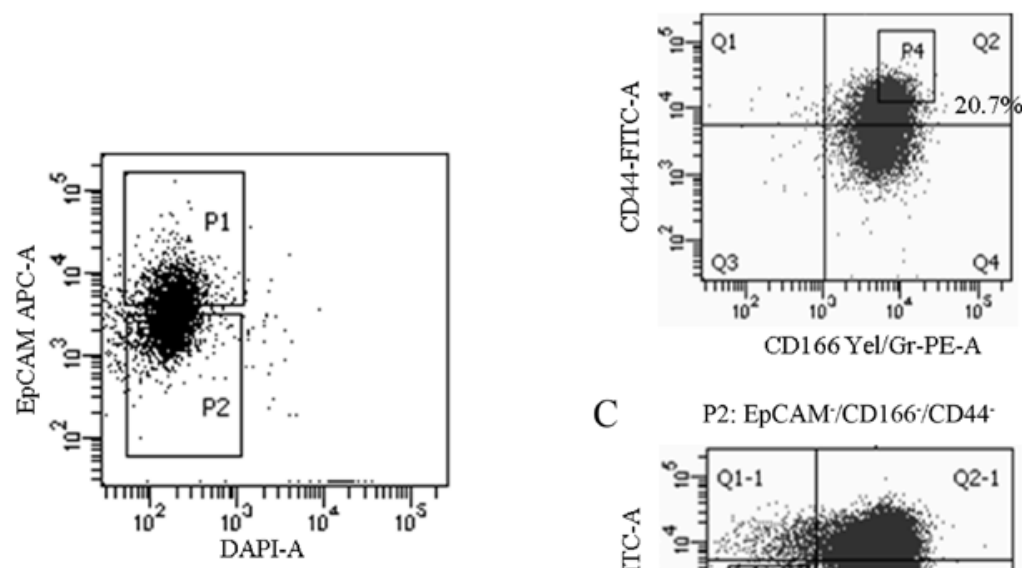

$\mathrm{C}$

P2: $\mathrm{EpCAM} / \mathrm{CD} 166 / \mathrm{CD} 44$

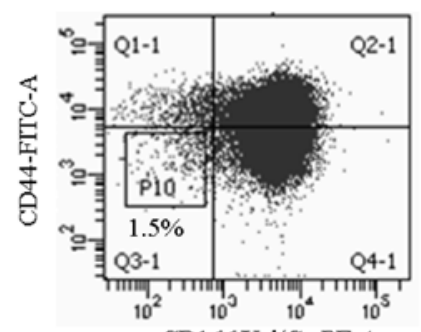

CD166 Yel/Gr-PE-A

Figure 1. Sorting of triple-positive $\left(\mathrm{EpCAM}^{+} / \mathrm{CD} 66^{+} / \mathrm{CD} 44^{+}\right)$and triple-negative (EpCAM/CD166/CD44) A549 cells. Cells were analysed using the surface markers of EpCAM (CD326)-APC, CD166-PE and CD44-FITC and sorted by FACS. (A) Cell debris and doublets were discriminated to differentiate between viable and dead cells before sorting, as indicated in the first three panels. (B and C) The expression of the triple-positive and the triple-negative subpopulations in A549 cells was $20.7 \%$ and $1.5 \%$, respectively.

meroclones and paraclones (Barrandon and Green) (37). For the analysis on the number of colonies formed, the cells were stained using Giemsa (Sigma-Aldrich, St. Louis, MO, USA) and were manually counted. In brief, the supernatant was aspirated and the wells were rinsed twice with PBS, followed by subsequent fixing with $4 \%$ formaldehyde for $2 \mathrm{~min}$ at $24^{\circ} \mathrm{C}$. Following fixation, the colonies were stained with Giemsa (Sigma-Aldrich) for $15 \mathrm{~min}$ in the dark at $24^{\circ} \mathrm{C}$. Following that, the excessive dye was removed and the stained colonies were set to air-dry before analysis and counting.

Spheroid assay. Both sorted [triple-positive $\left(\mathrm{EpCAM}^{+} /\right.$

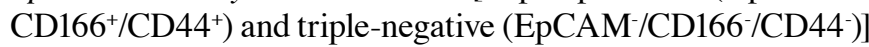
and unsorted A549 cells were suspended in serum-free sphere medium $\left(1.0 \times 10^{3}\right.$ cells $\left./ \mathrm{ml}\right)$ containing DMEM-F12 (Gibco; Thermo Fisher Scientific, Inc.) supplemented with $10 \mathrm{ng} / \mathrm{ml}$ basic fibroblast growth factor (bFGF; Life Technologies, Foster City, CA, USA), $1 \%$ of B27 supplement (Life Technologies), $20 \mathrm{ng} / \mathrm{ml}$ of epidermal growth factor (EGF; Life Technologies), $100 \mathrm{IU} / \mathrm{ml}$ penicillin and $100 \mu \mathrm{g} / \mathrm{ml}$ streptomycin (Life Technologies). The cells were re-suspended in a ratio of 1:1 (v/v) of growth factor-reduced Matrigel (BD Biosciences) and serum-free sphere medium. The cells were then seeded in a 96-well ultra-low attachment (ULA) dish (Corning, Inc., Oneonta, NY, USA). The size and number of the formed spheroids were assessed after 20 days of culture by inverted phase contrast microscopy (Olympus).

Chemotherapy-resistance assay. The viability of both sorted and unsorted A549 cells was assessed by MTS assay following treatment with 5-fluouracil (5-FU) and cisplatin. Briefly, the cells were seeded at a concentration of $1 \times 10^{4}$ cells/well in a 96-well plate and were incubated overnight at $37^{\circ} \mathrm{C}$ in humidified air containing $5 \% \mathrm{CO}_{2}$. Subsequenlty, $5-\mathrm{FU}$ and cisplatin were added at different concentrations $(5,10,30,50,70$ and $90 \mu \mathrm{M}$ ) and incubated for $48 \mathrm{~h}$, and then, $15 \mu \mathrm{l}$ of MTS solution (CellTiter $96^{\circledR}$ AQueous One Solution; Promega) was added to each well and further incubated for another $4 \mathrm{~h}$. Solubilisation solution $(100 \mu \mathrm{l})$ was added to the cells and absorbance at $570 \mathrm{~nm}$ was assessed using Odyssey ${ }^{\circledR}$ Sa Imaging System (LI-COR Biosciences). Cell viability was calculated using the formula as aforementioned.

Aldehyde dehydrogenase detection (Aldefluor assay). The Aldefluor assay (StemCell Technologies, Vancouver, Canada) was performed according to the manufacturer's instructions. 
Table I. List of primers used in qRT-PCR for the expression of stem cell genes.

\begin{tabular}{llll}
\hline Gene & \multicolumn{1}{c}{ Accession } & \multicolumn{1}{c}{ Forward primer } & \multicolumn{1}{c}{ Reverse primer } \\
\hline$R E X 1$ & NM_174900 & GCGTACGCAAATTAAAGTCCAGA & ATCCTAAACCAGCTCGCAGAAT \\
SOX2 & NM_0031063 & CCCCCGGCGGCAATAGCA & TCGGCGCCGGGGAGATACAT \\
ABCG2 & NM_001257386 & GTTTATCCGTGGTGTGTCTGG & CTGAGCTATAGAGGCCTGGG \\
SSEA4 & NM_006927 & TGGACGGGCACAACTTCATC & GGGCAGGTTCTTGGCACTCT \\
NANOG & NM_001297698 & TCCTCCATGGATCTGCTTATTCA & CAGGTCTTCACCTGTTTGTAGCTGAG \\
OCT4 & NM_001173531 & CGACCATCTGCCGCTTTGAG & CCCCCTGTCCCCCATTCCTA \\
\hline
\end{tabular}

Briefly, a total of $2 \times 10^{5}$ cells were collected, centrifuged, pelleted and re-suspended in $500 \mu 1$ of assay buffer before the staining. Aldefluor stain $(2.5 \mu \mathrm{l})$ was added into the samples followed by the addition of $5 \mu \mathrm{l}$ ALDH1 inhibitor (diethylaminobenzaldehyde/DEAB) to the control tube. The cells were vortexed and incubated for $30 \mathrm{~min}$ at $37^{\circ} \mathrm{C}$ in the dark. Subsequently, the cells were centrifuged at $180 \mathrm{x}$ g for $5 \mathrm{~min}$ and the collected pellet was re-suspended in $500 \mu 1$ assay buffer before being subjected to flow cytometry (BD FACS Calibur; BD Biosciences) and analysed using BD CellQuest ${ }^{\mathrm{TM}}$ Pro software (BD Biosciences).

Mitochondrial membrane potential $\left(\Delta \psi_{m}\right)$ assay. Analysis of mitochondrial membrane potential was conducted using the BD MitoScreen (BD Biosciences). To determine the amount of cells undergoing mitochondrial membrane potential $\left(\Delta \psi_{\mathrm{m}}\right)$ in response to cisplatin, the cells were incubated in JC-1 stain (5,5',6,6'-tetrachloro-1,1',3,3'-tetraethylbenzimidazolcarbocyanine iodide) for $15 \mathrm{~min}$ at $37^{\circ} \mathrm{C}$ in the dark, and then were washed two times with $1 \mathrm{X}$ assay buffer. Analysis on the $\Delta \psi_{\mathrm{m}}$ was conducted based on the intensity of the fluorescence detected in both the FL-1 and FL-2 channels by using a flow cytometer (BD FACSCalibur; BD Biosciences).

Scratch-wound/migrationassay. Briefly,both sorted and unsorted A549 cells were seeded at a density of $\sim 3-4 \times 10^{5}$ cells/well (6-well plate) in complete RPMI-1640 medium and were grown overnight to $90 \%$ confluency. Then, the cells were incubated with colcemid $(10 \mu \mathrm{g} / \mathrm{ml})$ for $2 \mathrm{~h}$ for synchronization. After incubation, a scratch was created using a $200-\mu 1$ pipette tip and the wells were gently washed using PBS to remove any residual debris. Fresh complete RPMI-1640 medium ( $2 \mathrm{ml}$ ) was added followed by incubation for another $48 \mathrm{~h}$. The images of the migrated cells from five fields of view were captured using a relief-phase contrast microscope (Olympus IX71; Olympus) at x400 magnification. The cells migrated into the wound area were evaluated using the following formula: Percentage of cells migrated $=[$ Initial scratch $(0 \mathrm{~h})$ - Final scratch $(48 \mathrm{~h})]$ )/ Initial $(0 \mathrm{~h}) \times 100$.

Quantitative real time-polymerase chain reaction ( $q R T-P C R$ ). The mRNA expression of CSC markers in both sorted and unsorted A549 cells was determined by quantitative RT-PCR (qRT-PCR) using a LightCycler 480 (Roche, Mannheim, Germany). Initially, the total RNA was extracted from both cells using an RNAeasy extraction kit (Qiagen, Hamburg, Germany) according to the manufacturer's protocol. Subsequently, cDNA was synthesised from $1 \mu \mathrm{g}$ of total RNA using a Transcriptor First Strand cDNA Synthesis kit (Roche Applied Science, Mannheim, Germany). The qRT-PCR reaction was prepared using a SYBR 1 Master Mix (Roche) as well as different sets of primers (REX1, SOX2, ABCG2, SSEA4, NANOG, OCT4 and $G A P D H$ ) as displayed in Table I. The PCR reactions were run under the following cycle conditions; a pre-denaturation step for $4 \mathrm{~min}$ at $95^{\circ} \mathrm{C}$ followed by 40 cycles of denaturation at $95^{\circ} \mathrm{C}$ for $15 \mathrm{sec}$, annealing at $60^{\circ} \mathrm{C}$ for $30 \mathrm{sec}$ and extension at $72^{\circ} \mathrm{C}$ for $30 \mathrm{sec}$. The basic relative gene expression (RQ) was calculated using the $\Delta \Delta \mathrm{Ct}$ formula and the efficiency (E) of a primer binding equal to 2 .

Statistical analysis. Results are expressed as the means \pm standard deviation (SD) of three independent experiments. Statistical analysis was performed using the IBM SPSS statistics version 21 (IBM Corp., Armonk, NY, USA). Comparisons between two groups were performed using the two-tailed t-test; P-values $<0.01$ were considered to indicate statistically significant differences. Comparisons among groups were performed using one factor analysis of variance (ANOVA) followed by the Tukey's post hoc test.

\section{Results}

Expression of triple-positive (EpCAM+/CD166 $\left.{ }^{+} / \mathrm{CD}^{+} 4^{+}\right)$and triple-negative (EpCAM $\left./ C D 166 \% C D 44^{-}\right)$subpopulations in the A549 cell line. To identify the subpopulation believed to exhibit the putative CSC characteristics, we analysed and sorted subpopulations in the A549 cell line that expressed all three stem cell surface markers (EpCAM, CD166 and CD44), namely the triple-positive $\left(\mathrm{EpCAM}^{+} / \mathrm{CD} 166^{+} / \mathrm{CD}^{4} 4^{+}\right)$, and the triple-negative (EpCAM-/CD166/CD44) as controls (Fig. 1). Our findings indicated that the expression of EpCAM, CD166 and CD44 markers in the A549 cell line that was positive for all three markers $\left(\mathrm{EpCAM}^{+} / \mathrm{CD} 166^{+} / \mathrm{CD} 44^{+}\right)$was $20.7 \%$ (Fig. 1B), compared to only $1.5 \%$ concerning the expression of the triple-negative (EpCAM-/CD166 $/ \mathrm{CD}^{-} 4^{-}$) subpopulation (Fig. 1C). Both the triple-positive $\left(\mathrm{EpCAM}^{+} / \mathrm{CD} 166^{+} / \mathrm{CD}^{4} 4^{+}\right)$ and triple-negative (EpCAM-/CD166 $/ \mathrm{CD}^{-} 4^{-}$) subpopulations were sorted from the parental A549 cell line and cultureexpanded for further downstream analysis.

Proliferation activity of sorted and unsorted A549 cells. Higher density of cells was observed for both the unsorted 
A

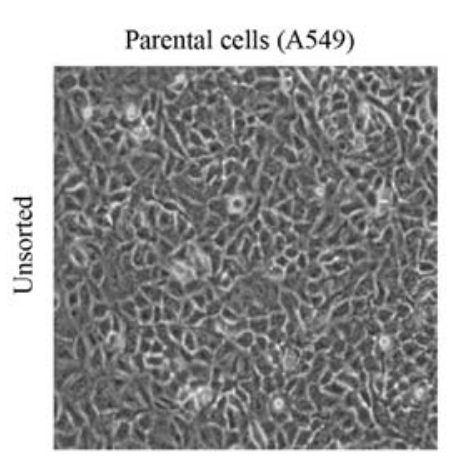

B

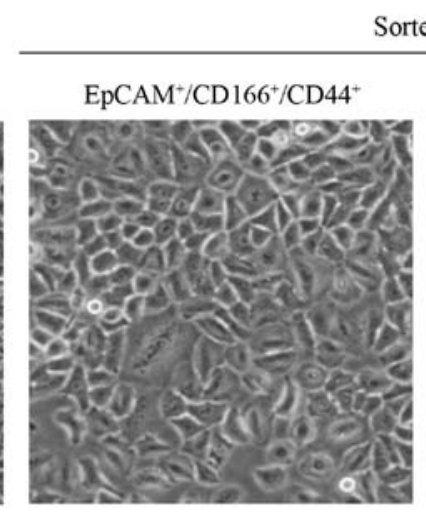

$\mathrm{C}$

C Telomerase reverse transcriptase/ hTERT gene

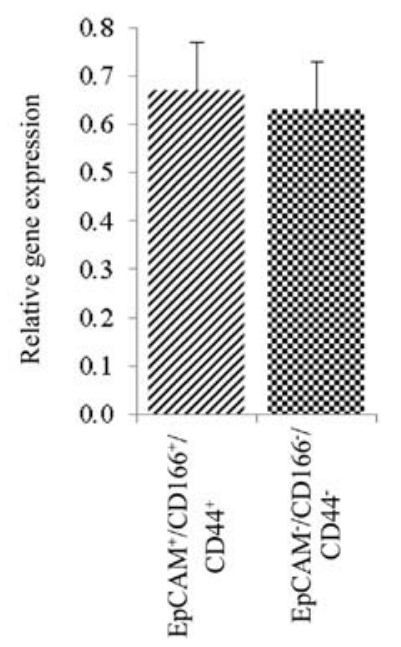

Figure 2. Cell proliferation activity of triple-positive $\left(\mathrm{EpCAM}^{+} / \mathrm{CD} 166^{+} / \mathrm{CD}_{4} 4^{+}\right)$and triple-negative $\left(\mathrm{EpCAM}^{-} / \mathrm{CD} 166 / \mathrm{CD}^{-} 4^{-}\right)$subpopulations in the NSCLC A549 cell line. (A) The cells were cultured in a 96-well plate at a density of $1 \times 10^{3}$ cells/well and the proliferation activity was assessed by absorbance at $570 \mathrm{~nm}$. Images were captured showing higher number of cells in both the unsorted and triple-positive compared to the triple-negative subpopulations at $72 \mathrm{~h}$ post incubation. (B) The triple-positive subpopulation exhibited significantly higher absorbance reading between 48 and $72 \mathrm{~h}$ compared to the triple-negative subpopulation indicating higher proliferative activity of these cells. (C) Analysis of the $h T E R T$ resulted in slightly higher expression of the gene in the triple-positive subpopulation, however there was no significant difference noticed between both subpopulations ( $\left(\mathrm{P}<0.01,{ }^{* * *} \mathrm{P}<0.001 ; \mathrm{t}\right.$-test).

and triple-positive subpopulation as compared to the triple-negative subpopulation (Fig. 2A). Based on the MTS activity, the triple-positive subpopulation $\left(\mathrm{EpCAM}^{+} / \mathrm{CD} 166^{+} /\right.$ $\mathrm{CD}_{4} 4^{+}$) demonstrated higher cellular proliferative activities compared to the triple-negative subpopulation (EpCAM $\%$ CD166-CD44-) between 48 and $72 \mathrm{~h}$ (Fig. 2B). In addition, the proliferative activity of the unsorted cells, which comprised of a heterogeneous population was almost similar to that of the triple-positive subpopulation (Fig. 2B), indicating that the triple-positive subpopulation is the main contributor to the cell proliferation activity. Analysis on the hTERT gene expression between both the triple-positive and negative subpopulations revealed an equal hTERT activity indicating high proliferative activity in both subpopulations (Fig. 2C).

Triple-positive (EpCAM+/CD166 $\left./ \mathrm{CD}^{+} 4^{+}\right)$subpopulation reveals compact clone formation as an indicator of 'stemness'. The results revealed that the formation of holoclones was significantly higher $(\mathrm{P}<0.05)$, with $75.5 \pm 7.8$ clones identified in the triple-positive $\left(\mathrm{EpCAM}^{+} / \mathrm{CD} 166^{+} / \mathrm{CD} 44^{+}\right)$subpopulation, compared to only $23.0 \pm 11.3$ clones in the triple-negative subpopulation and $41.5 \pm 12.0$ clones in the unsorted cells
(Fig. 3). Notably, we noticed that the triple-negative subpopulation presented with substantially higher meroclones with $65.5 \pm 10.6$ clones detected, compared to the triple-positive subpopulation and unsorted cells with only $23.0 \pm 1.4$ clones and $33.5 \pm 16.3$ clones detected, respectively (Fig. 3).

Triple-positive (EpCAM+/CD166 $\left./ \mathrm{CD}^{+} 4^{+}\right)$subpopulation demonstrates the ability to form spheres. The study was further validated through the investigation of the self-renewal capability of the sorted cells using a spheroid formation assay. Bigger spheroids reaching an average diameter of $142.7 \pm 31.6 \mu \mathrm{m}$ in size were found in the triple-positive $\left(\mathrm{EpCAM}^{+} / \mathrm{CD} 66^{+} / \mathrm{CD} 44^{+}\right)$subpopulation (Fig. 4A). In addition, there were smaller spheroids in the unsorted and the triple-negative (EpCAM-/CD166/CD44) subpopulation corresponding to an average spheroid diameter of $112.6 \pm 30.7$ and $63.0 \pm 23.2 \mu \mathrm{m}$, as depicted in Fig. 4B. Although both the unsorted and the triple-negative subpopulations were able to form spheroids, which indicated the self-renewal capability of these cells, these characteristics were more noticeable in the triple-positive subpopulation which developed larger sizes of formed spheroids. 

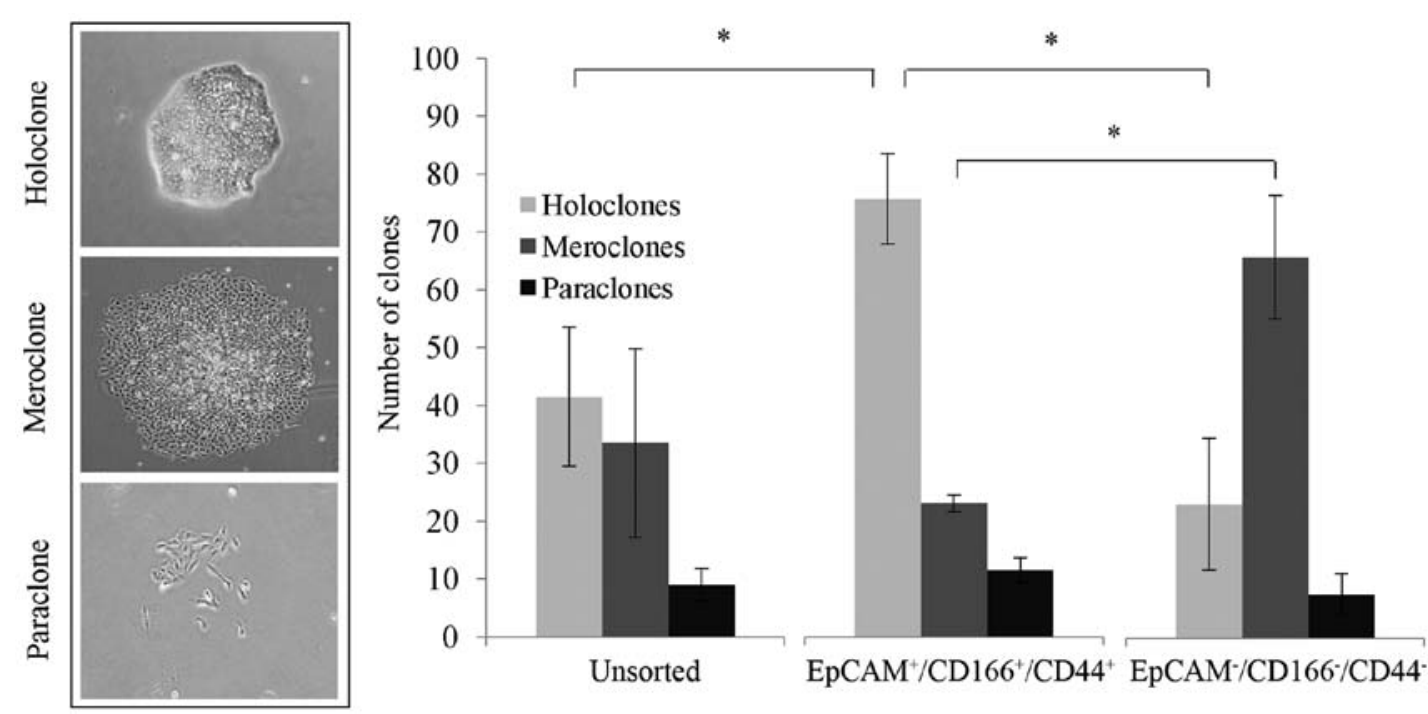

Figure 3. Comparison of clonal heterogeneity (holoclones, meroclones and paraclones) between the unsorted and sorted subpopulations of A549 cells. Cells were seeded at a density of $1 \times 10^{3}$ cells/well and grown in a 6 -well plate for 14 days. The triple-positive $\left(\mathrm{EpCAM}^{+} / \mathrm{CD} 166^{+} / \mathrm{CD}_{4} 4^{+}\right)$cells showed higher number of holoclones signifying the stem cell characteristic of the subpopulation, while the triple-negative (EpCAM//CD166/CD44) cells presented with greater number of meroclones indicating that the subpopulation exhibited mostly differentiated CSCs ( $\mathrm{P}<0.01$; t-test).

A

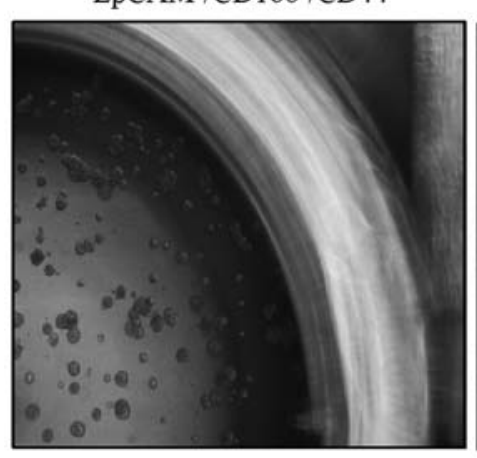

B

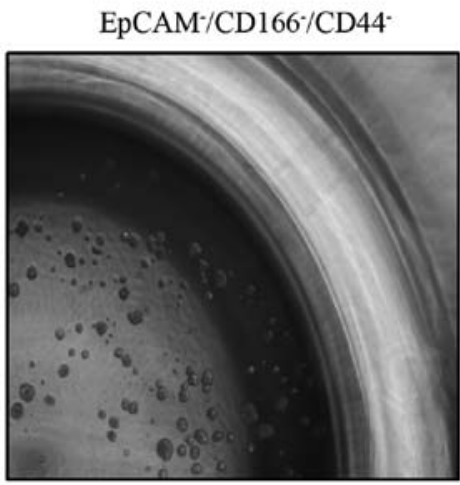

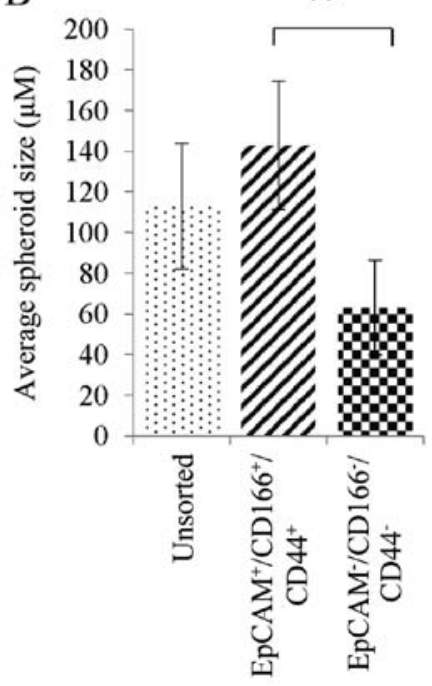

Figure 4. Potential of sorted (EpCAM ${ }^{+} / \mathrm{CD} 166^{+} / \mathrm{CD} 44^{+}$and EpCAM$\left./ \mathrm{CD} 166^{-} / \mathrm{CD} 44^{-}\right)$subpopulations to form spheroids under serum-free culture condition. (A) Cells were seeded at a density of 500 cells/well in a 24 -well ultra-low attachment plate. The triple-positive $\left(\mathrm{EpCAM}^{+} / \mathrm{CD} 66^{+} / \mathrm{CD} 44^{+}\right)$subpopulation formed bigger anchorage independent spheroids compared to the triple-negative (EpCAM-/CD166-/CD44-) subpopulation after 14 days of culture. (B) The images showing the sizes of spheres in each well indicated in A, were subsequently analysed as depicted in B. The error bar indicated the average standard deviation of triplicate experiments $\left({ }^{* *} \mathrm{P}<0.001\right.$; t-test).

Chemotherapy-resistant properties of triple-positive $\left(\right.$ EpCAM $\mathrm{M}^{+} / \mathrm{CD}_{\left.166^{+} / C D 44^{+}\right)}$subpopulation. To investigate the chemotherapy-resistant properties of the triple-positive $\left(\mathrm{EpCAM}^{+} / \mathrm{CD} 166^{+} / \mathrm{CD}_{4} 4^{+}\right)$subpopulation, the cells were separately exposed to increasing doses of 5-FU and cisplatin,

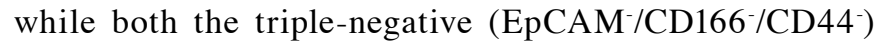
subpopulation and the unsorted cells were used as controls. When the cells were exposed to an increased concentration of 5-FU, the percentage of proliferation in the triple-positive subpopulation was markedly higher $(\mathrm{P}<0.01)$, compared to both the triple-negative subpopulation and the unsorted cells (Fig. 5A). Similarly, higher proliferation rate in the triple-positive subpopulation was noticed compared to the triple-negative subpopulation upon exposure to increasing cisplatin concentrations (Fig. 5B). Our findings also indicated a significant difference $(\mathrm{P}<0.01)$ in the $\mathrm{IC}_{50}$ values of the triple-positive subpopulation with $876.3 \pm 260.7$ and $65.3 \pm 6.9 \mu \mathrm{M}$ detected compared to the triple-negative subpopulation with only 9.5 \pm 1.2 and $35.6 \pm 4.1 \mu \mathrm{M}$ after exposure of both subpopulations to 5-FU and cisplatin, respectively (Table II).

\section{High ALDH1 activity in the triple-positive (EpCAM ${ }^{+} / \mathrm{CDI}^{+} 6^{+} /$ $\left.C D 44^{+}\right)$subpopulation. The chemo-resistance characteristic was further investigated through analysis of ALDH activity

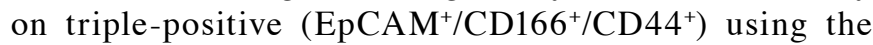 Aldefluor $^{\mathrm{TM}}$ kit (StemCell Technologies, Vancouver, BC,}



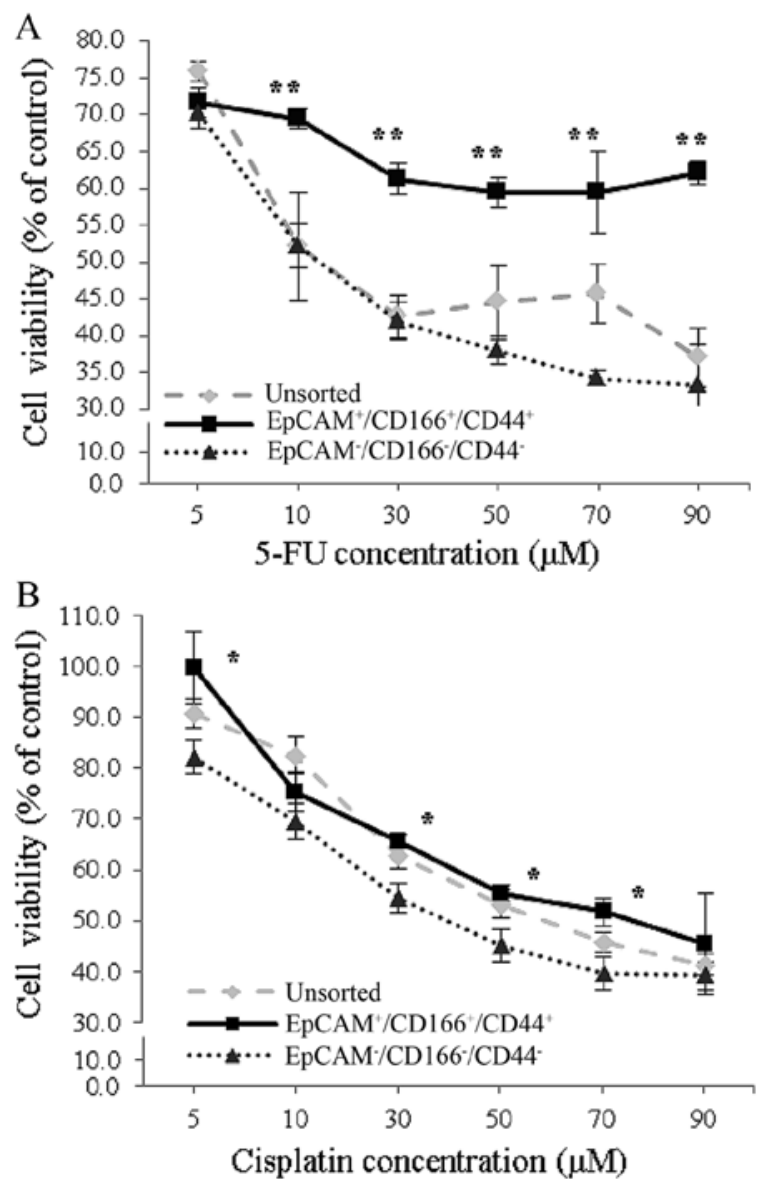

Figure 5. Comparison of cell viability between the triple-positive $\left(\mathrm{EpCAM}^{+} /\right.$ $\left.\mathrm{CD} 166^{+} / \mathrm{CD}^{2} 4^{+}\right)$and triple-negative (EpCAM-/CD166/CD44) subpopulations during chemotherapy-induced cytotoxicity. (A and B) The cells were exposed to different concentrations $(5-90 \mu \mathrm{M})$ of chemotherapy (5-fluouracil, A; and cisplatin, B) for $72 \mathrm{~h}$, followed by analysis of cell viability using Cell Titter-96 ${ }^{\circledR}$ AQueous One Solution (Promega). The triple-positive subpopulation exhibited greater chemo-resistant characteristics while the triple-negative subpopulation was more sensitive to the treatments. The error bar indicated the average standard deviation of triplicate experiments $\left({ }^{*} \mathrm{P}<0.01,{ }^{* *} \mathrm{P}<0.001 ;\right.$ t -test $)$.

Canada). Our analysis revealed that the level of ALDH1 activity was significantly higher $(\mathrm{P}<0.05)$ in the triple-positive subpopulation with $80.47 \pm 1.9 \%$ expression level detected, compared to the triple-negative (EpCAM-/CD166 ${ }^{-} / \mathrm{CD}^{-} 4^{-}$) subpopulation $(67.88 \pm 0.7 \%)$ as displayed in Fig. 6. Furthermore, the expression level of ALDH1 in the unsorted cells was $76.26 \pm 0.1 \%$, which was almost equal to the expression observed in the triple-positive subpopulation indicating that the ALDH1 activity of the unsorted cells was mostly contributed to the chemo-resistant characteristic of the triple-positive subpopulation (Fig. 6).

Mitochondrial membrane potential $\left(\Delta \psi_{m}\right)$ activity of the triple-positive (EpCAM+CD166 $\left./ C D 44^{+}\right)$subpopulation . Chemotherapeutic drugs were able to stimulate changes of the inner mitochondrial membrane and subsequently cause the loss of mitochondrial membrane potential $\left(\Delta \psi_{\mathrm{m}}\right)$. Using the JC-1 stain, both unsorted and sorted cells were treated with cisplatin and the $\Delta \psi_{\mathrm{m}}$ was subsequently evaluated analysing the JC-1 monomers (green fluorescence) on the FL-2 channel. Our findings indicated that cisplatin treatment resulted in a
Table II. $\mathrm{IC}_{50}$ values of the A549 cell line subpopulations.

\begin{tabular}{|c|c|c|}
\hline \multirow[b]{2}{*}{$\begin{array}{l}\text { A549 cell } \\
\text { subpopulation }\end{array}$} & \multicolumn{2}{|c|}{$\begin{array}{l}\mathrm{IC}_{50} \text { values }(\mu \mathrm{M}) \\
\text { for the treatments }\end{array}$} \\
\hline & 5-fluouracil (5-FU) & Cisplatin \\
\hline Unsorted & $27.8 \pm 6.3$ & $59.2 \pm 7.9$ \\
\hline $\mathrm{EpCAM}^{+} / \mathrm{CD} 166^{+} / \mathrm{CD} 44^{+}$ & $876.3 \pm 260.7$ & $65.3 \pm 6.9$ \\
\hline EpCAM-/CD166\%/CD44- & $9.5 \pm 1.2$ & $35.6 \pm 4.1$ \\
\hline
\end{tabular}

Results are the mean \pm standard deviation $(\mathrm{SD})$. The $\mathrm{IC}_{50}$ values were determined as specified in Materials and methods.

greater percentage of FL-2 value of $18.9 \pm 1.9 \%$ as detected in the triple-positive $\left(\mathrm{EpCAM}^{+} / \mathrm{CD} 166^{+} / \mathrm{CD}_{4} 4^{+}\right)$subpopulation. This was followed by the triple-negative (EpCAM-/CD166\%

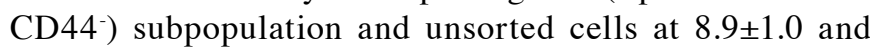
$15.1 \pm 0.76 \%$, respectively (Fig. 7). Depolarizarion of the $\Delta \psi_{\mathrm{m}}$ indicated a strong activity of the cells undergoing early apoptosis which was detected at a high level in the triple-positive subpopulation.

Triple-positive (EpCAM+/CD166 $\left./ C D 44^{+}\right)$subpopulation exhibits high epithelial to mesenchymal transition (EMT) characteristics. The following assay was conducted by evaluating the migration ability of the triple-positive $\left(\mathrm{EpCAM}^{+} / \mathrm{CD} 166^{+} / \mathrm{CD} 44^{+}\right)$subpopulation compared to the

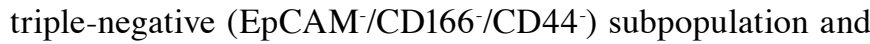
unsorted cells. Using an in vitro migration model, scratch assay was analysed on day 2 and 3 (Fig. 8). The triple-positive subpopulation demonstrated significantly higher migration $(\mathrm{P}<0.01)$ with $56.1 \pm 1.4$ and $87.6 \pm 2.5 \%$ wound closure detected on day 2 and day 3 , respectively. The findings were compared to the triple-negative subpopulation (with only $19.9 \pm 1.7 \%$ wound closure on day 2 and $51.9 \pm 6.3 \%$ on day 3 ) and indicated that the triple-positive subpopulation had a higher EMT activity.

Triple-positive (EpCAM+/CD166 $/ C D 44^{+}$) subpopulation of the A549 cell line exhibits the profile of stem cell-associated genes. Finally, to further confirm the intrinsic stem cell properties of the triple-positive $\left(\mathrm{EpCAM}^{+} / \mathrm{CD} 166^{+}\right.$ $\mathrm{CD}_{44^{+}}$) subpopulation, the expression of SSEA4, REX1, and $A B C G 2$ was analysed using the quantitative gene analysis. The triple-positive subpopulation exhibited significantly higher $(\mathrm{P}<0.001)$ expression of the specific pluripotent gene,

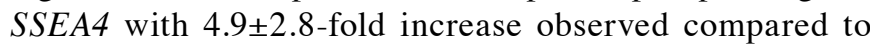
the triple-negative subpopulation (Fig. 9A). Slight increase $(\mathrm{P}<0.05)$ was observed for the specific stem cell gene, $R E X 1$ in the triple-positive subpopulation compared to the triple-negative subpopulation as depicted in Fig. 9B. This event indicated that the triple-positive subpopulation possessed the features of stem cells as evidenced by the expression of markers related to CSC development. However, no significant differences were detected for the $A B C G 2$ gene expression between the triple-positive and triple-negative subpopulations (Fig. 9C). 

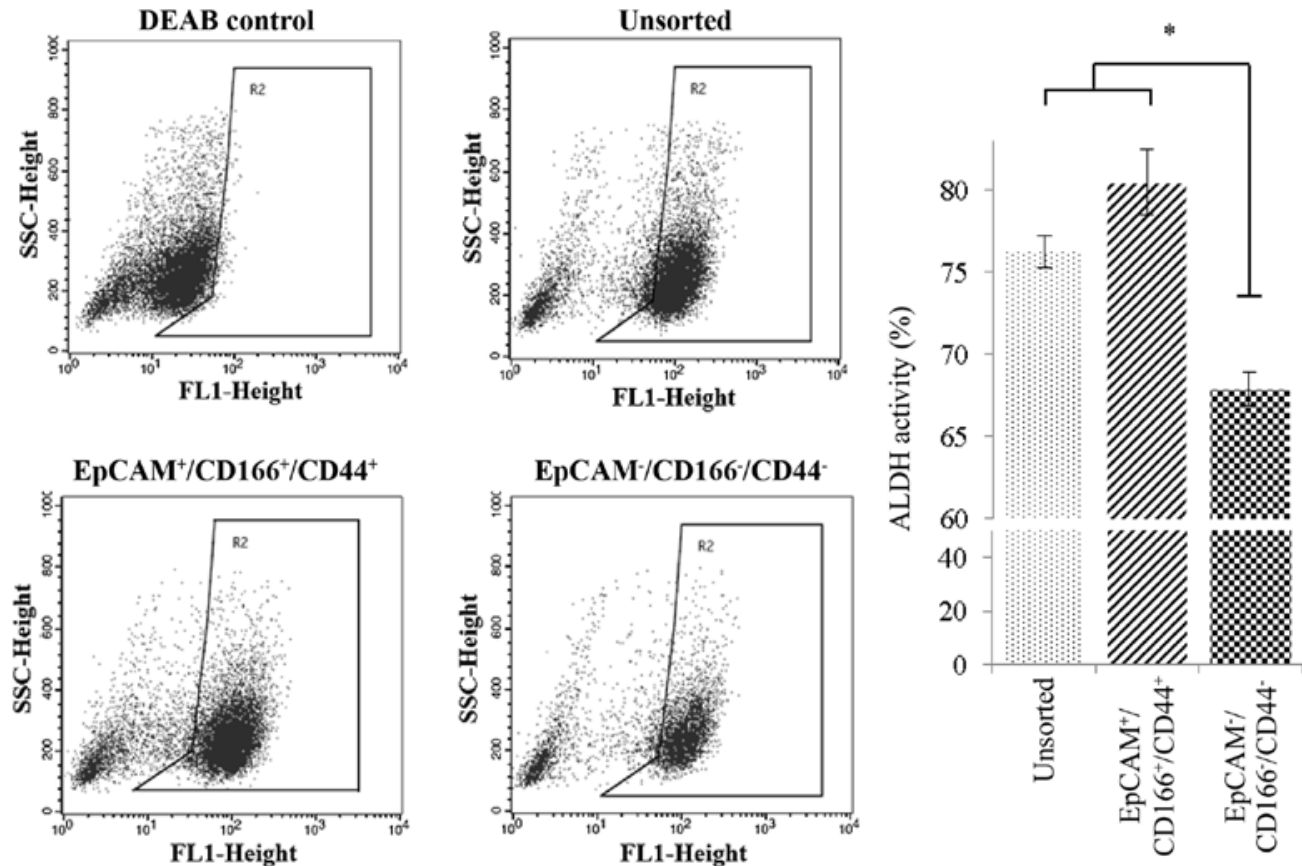

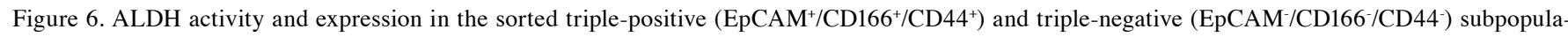
tions and unsorted cells derived from the A549 cell line. The triple-positive $\left(\mathrm{EpCAM}^{+} / \mathrm{CD} 166^{+} / \mathrm{CD}_{4} 4^{+}\right)$subpopulation presented with higher ALDH activity $(80.46 \%)$, compared to the triple-negative (EpCAM $\left./ \mathrm{CD}^{-6} 6^{-} / \mathrm{CD}^{-} 4^{-}\right)$subpopulation with only $67.88 \%$ detected, indicating the resistant characteristic of the triple-positive subpopulation to common treatments and the lower sensitivity of this subpopulation to common chemotherapy. The error bar indicated the average standard deviation of triplicate experiments $\left({ }^{*} \mathrm{P}<0.01,{ }^{* *} \mathrm{P}<0.001 ; \mathrm{t}\right.$-test).
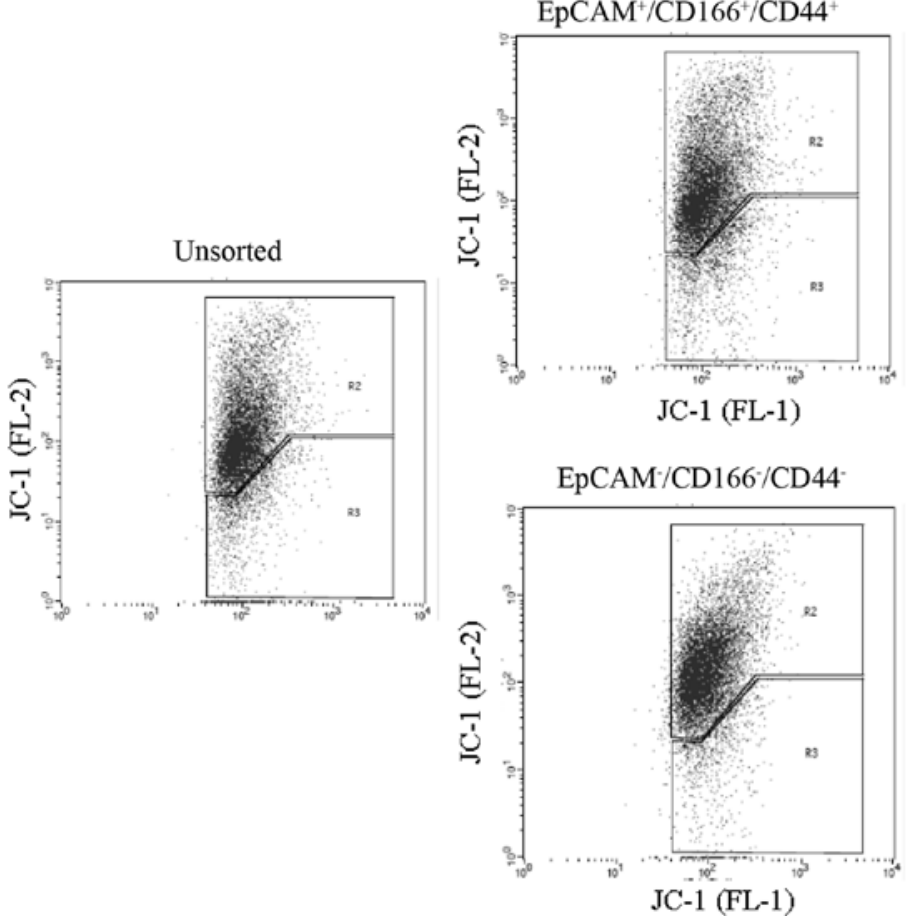

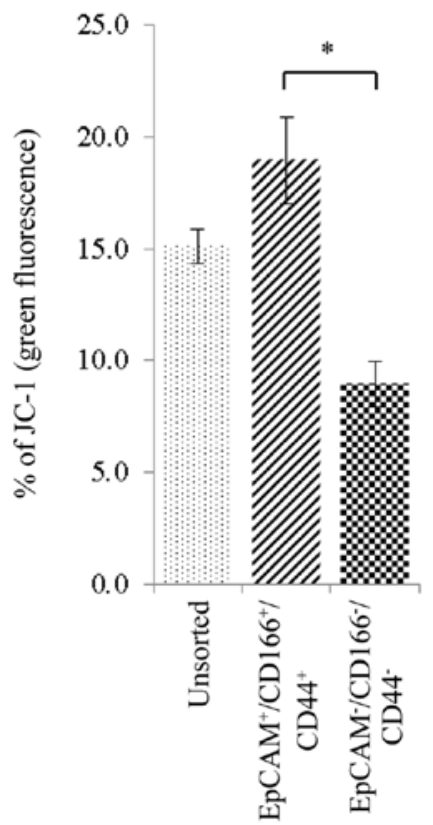

Figure 7. Observation of the mitochondrial membrane potential $\left(\Delta \psi_{\mathrm{m}}\right)$ in the triple-positive $\left(\mathrm{EpCAM}^{+} / \mathrm{CD} 166^{+} / \mathrm{CD}_{4} 4^{+}\right)$and triple-negative $\left(\mathrm{EpCAM} / \mathrm{CD}^{-} 66^{-} /\right.$ $\mathrm{CD} 44^{-}$) subpopulations prior to treatment with cisplatin. Cells were grown and treated with cisplatin for $72 \mathrm{~h}$ and stained with the JC-1 for $15 \mathrm{~min}$ at $37^{\circ} \mathrm{C}$ in the dark. The fluorescence intensity was detected using flow cytometry and the percentage of the $\Delta \psi_{\mathrm{m}}$ was gated on the R1 area. The error bars indicated the average standard deviation of triplicate experiments $\left({ }^{\circ} \mathrm{P}<0.01,{ }^{* * *} \mathrm{P}<0.001\right.$; $\mathrm{t}$-test).

\section{Discussion}

To the best of our knowledge, the present study is the first to investigate and confirm the existence of a novel CSC subpopulation based on the presence of three surface markers, EpCAM, CD166 and CD44 combined, in which these markers can specifically identify and discriminate a distinctive subpopulation of putative CSCs in NSCLC. It has been 
A
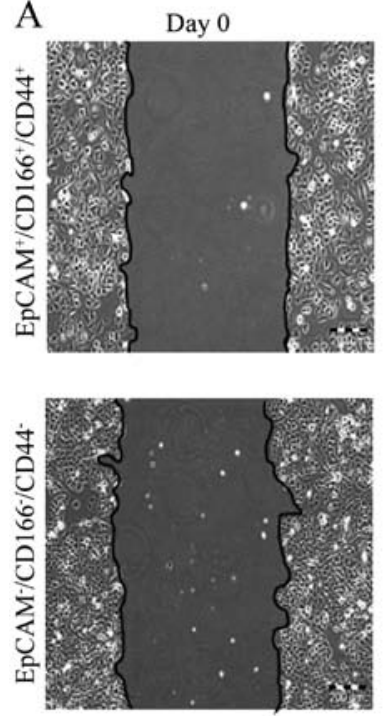

B
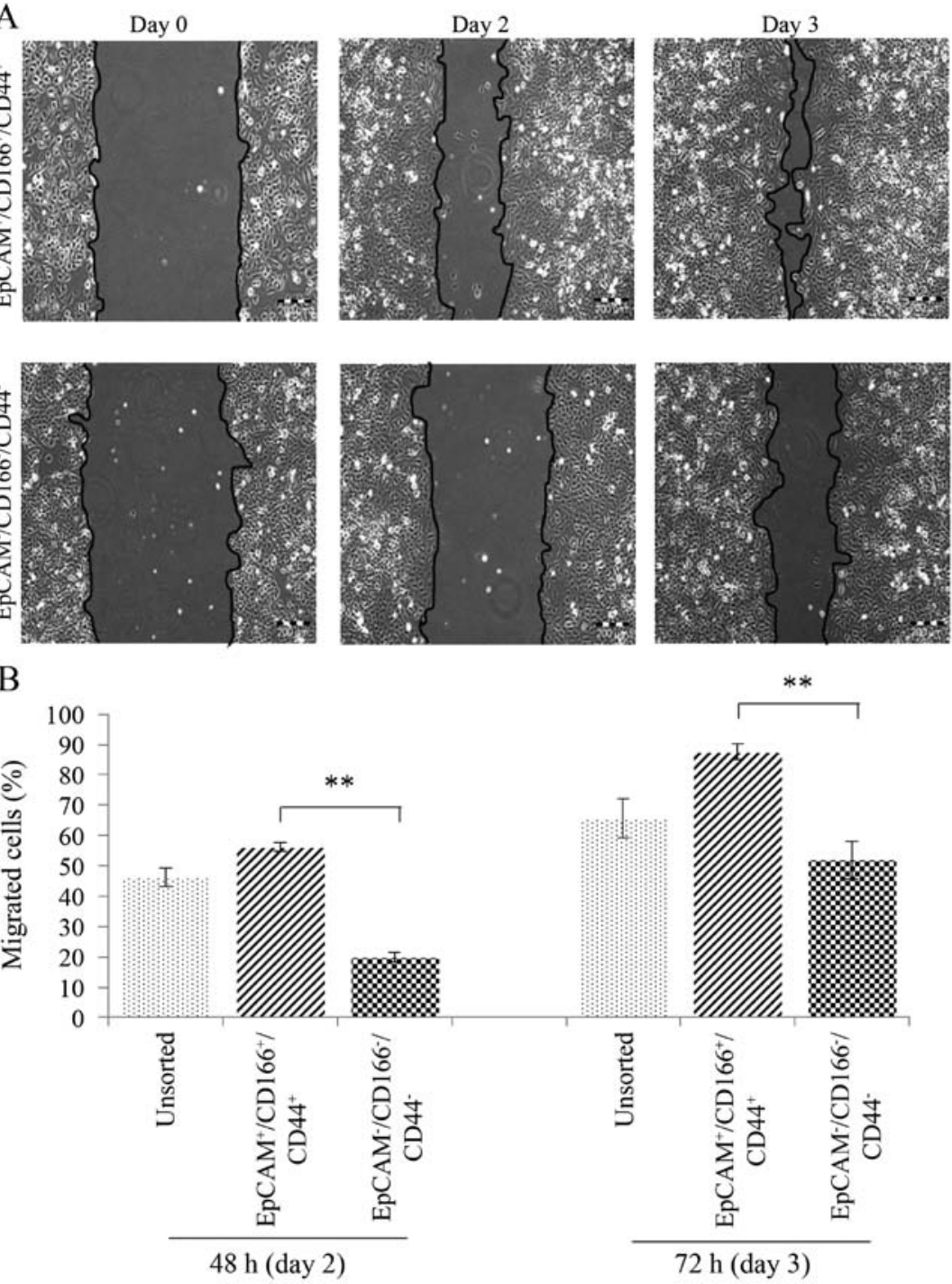

Figure 8. The triple-positive (EpCAM ${ }^{+} / \mathrm{CD} 66^{+} / \mathrm{CD} 44^{+}$) subpopulation exhibits higher cellular migratory and metastatic potential. (A) Representative photomicrographs and analysis of wound closure were presented for the sorted (EpCAM ${ }^{+} / \mathrm{CD} 166^{+} / \mathrm{CD}_{4} 4^{+}$and EpCAM $/ \mathrm{CD}^{-} 66^{-} / \mathrm{CD}^{-} 4^{-}$) subpopulations and the unsorted A549 cell line. Higher migratory potential was observed in the triple-positive compared to the triple-negative subpopulation at day 2 and day 3 indicating higher metastatic ability of this subpopulation compared to the control. (B) Wound closures were subsequently analysed as depicted in the graph. The error bar indicated the average standard deviation of triplicate experiments $\left({ }^{* *} \mathrm{P}<0.001 ; \mathrm{t}\right.$-test $)$.
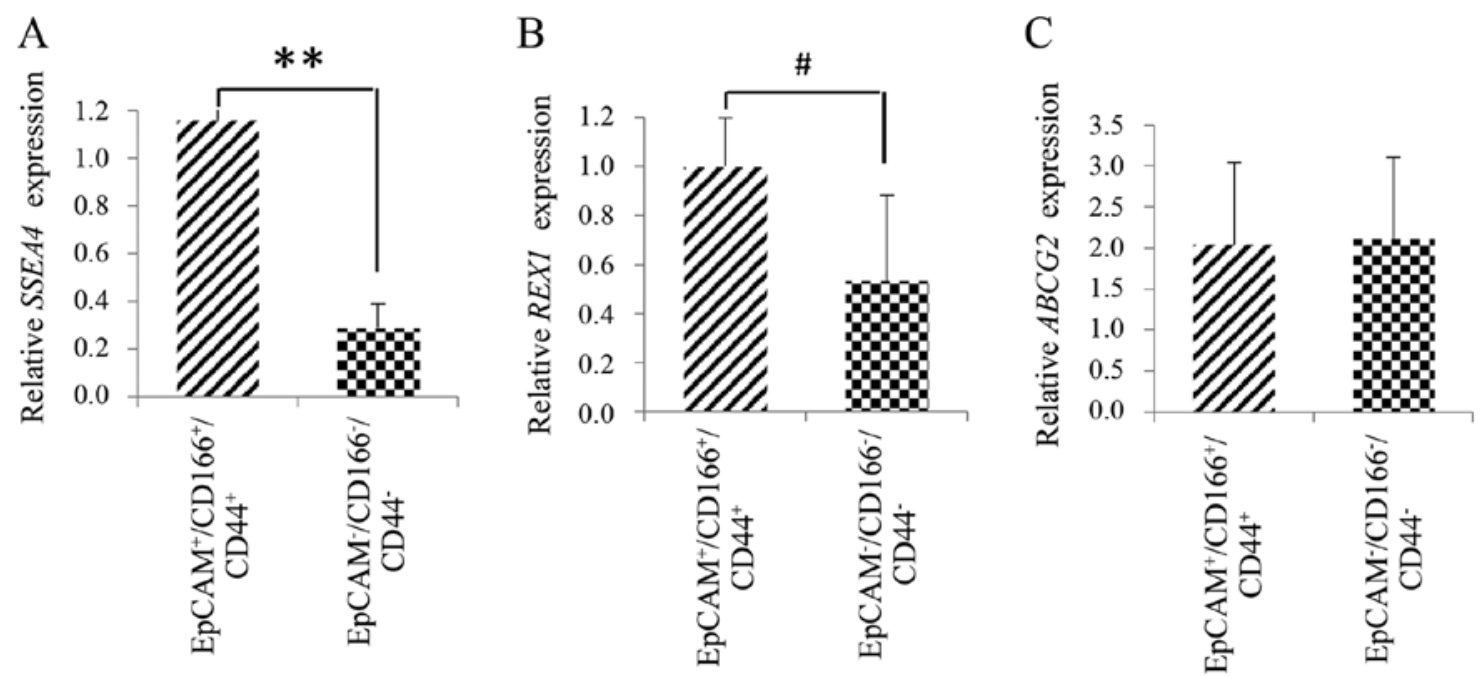

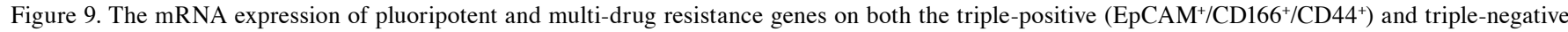
(EpCAM $/ \mathrm{CD} 166^{-} / \mathrm{CD}_{4} 4^{-}$) subpopulations. The mRNA expression of (A) SSEA4, (B) REX1 and (C) ABCG2 was analysed using qRT-PCR and the unsorted cells with GAPDH were used as an internal control $\left({ }^{\#} \mathrm{P}<0.05,{ }^{* *} \mathrm{P}<0.001 ;\right.$ t-test $)$. 
hypothesised that by eliminating this subpopulation, treatment efficacy would be enhanced and chances of tumour relapse reduced. However, the heterogeneity of CSCs is the major impediment that needs to be overcome in order to achieve a better treatment goal. Therefore, a marker that is both robust and specific to identify the major CSC subpopulation is an effective approach for lung cancer treatment. In our previous study, we have identified a potential CSC subpopulation using the combination of two markers from three surface markers (CD166, CD44 and EpCAM) that significantly discriminated CSCs from the non-CSCs in NSCLC (38). Furthermore, we also concluded that these subpopulations $\left(\mathrm{CD} 166^{+} / \mathrm{EpCAM}^{+}\right.$ and $\mathrm{CD} 166^{+} / \mathrm{CD} 44^{+}$) exhibited the transcriptomic profile of multipotent cells including the self-renewal capacity, ability for adipogenic, as well as osteogenic differentiation and upregulation of the CSC gene pathways, that further confirmed the stemness characteristics of these subpopulations. In addition, the in vivo study also confirmed the tumourigenic capacity presented by the ability of these subpopulations to generate bigger tumour bulk, compared to their non-CSCs counterpart (CD166/EpCAM ${ }^{-}$and CD166/CD44-) (38). Therefore, these findings have paved the way to the present study of using a combination of all three markers simultaneously in order to have a stringent selection of CSCs in NSCLC.

Isolating CSCs from the A549 cell line using a combination of all three markers (EpCAM, CD166 and CD44) resulted in two subpopulations known as the triple-positive $\left(\mathrm{EpCAM}^{+} / \mathrm{CD} 166^{+} / \mathrm{CD}_{4} 4^{+}\right)$and triple-negative (EpCAM ${ }^{-}$ CD166-/CD44-). In the present study, we found that the triple-positive subpopulation presented with $20.7 \%$ expression of the combined markers (Fig. 1), which was higher than the expected percentage of CSCs reported in other studies $(39,40)$. Although the expression was high and may indicate that the combination marker was unspecific, numerous studies have reported the validity of these markers in detecting specific CSC subpopulations, either as single markers, e.g., CD166 (41) and CD44 (42) or co-expressed with other known CSC markers such as CD90 (43) and CD133 (44). Our findings indicated that the triple-positive markers, although highly expressed in the A549 cell line, may serve as specific and yet robust markers that can discriminate a large population of lung CSCs from the non-CSCs due to their high specificity detected in several tumours.

According to Barrandon and Green (1987) (45) who described different clonogenicity to multiplication characteristics, only colonies known as holoclones (colonies with well-defined border) with cellular characteristics of pluripotent stem cells (i.e., high nuclear to cytoplasmic ratio, prominent nucleolus and small cell size) were capable of extensive proliferation, self-renewal and cellular growth. However, the meroclones and paraclones (colonies without a well-defined border) had a limited proliferation capacity and were incapable of self-renewal. From our findings, we observed that in contrast to the triple-negative subpopulation, the triple-positive subpopulation could give rise to higher number of holoclones (Fig. 3). Furthermore, the triple-negative subpopulation consisted of mostly meroclones, indicating that the subpopulation was predominantly governed by differentiated types of CSCs. We also observed that the triple-positive subpopulation had the ability to form bigger spheroids (Fig. 4) compared to its counterpart. Significance in the size of spheroids between the putative CSCs and non-CSCs by in vitro analysis that may also reflex the bulk of tumours in xenografts has been reported as an indicator of CSC stemness in numerous studies. The triple-negative subpopulation may also form spheroids as these cells are also tumour cells, however the observation that they were significantly smaller than the triple-positive subpopulation cells indicated its level of tumourigenicity (46). Collectively, the results indicated that the triple-positive subpopulation has the fundamental characteristic of stemness (Figs. 3 and 4) (47).

In addition to clonogenicity, chemoresistance is also an equally important characteristic that can clearly define a typical feature of CSC (48). Since the expression of ALDH1 was high in the triple-positive subpopulation (Fig. 6), it was plausible that the subpopulation was resistant to both cisplatin and 5-FU treatments when compared to the triple-negative subpopulation (Fig. 5). Furthermore, enriched CSCs such as the triple-positive subpopulation would have a lower sensitivity to common chemotherapy as reflected by the higher cell viability post treatment, compared to the unsorted cells where the sensitivity to chemotherapy was higher due to the existence of non-CSCs in their population $(49,50)$. This finding was in line with previous studies that have revealed a similar observation in $\mathrm{CD}_{133^{+}}$subpopulation derived from colon cancer cells and pretreated with both oxaliplatin and 5-FU (51). The chemotherapy-resistant activity, as confirmed by gene expression analysis, has recently been reported as a potential marker that can specifically discriminate CSCs from non-CSCs $(52-55)$ in different tumour types $(52,53,56)$ However, our observation in the expression of $A B C G 2$ mRNA (a multidrug resistance family gene) indicated no differences between the triple-positive and triple-negative subpopulations (Fig. 9). Nonetheless, it is believed that the ABCG2 may not directly influence the chemoresistant characteristic of this subpopulation. Therefore, screening for several other multidrug resistance genes such as the $A B C G 1, P$-glycoprotein and $M D R$ family were necessary in order to fully characterise the chemo-resistant activity of this subpopulation.

There was higher loss of mitochondrial membrane potential $\left(\Delta \psi_{\mathrm{m}}\right)$ in the triple-positive subpopulation following cisplatin treatment, than the triple-negative subpopulation indicating that this particular subpopulation was more sensitive to the treatment. The treatment also induced loss of the $\Delta \psi_{\mathrm{m}}$ activity which eventually led to an activation of the intrinsic apoptotic pathways in both subpopulations $(57,58)$. A higher $\Delta \psi_{\mathrm{m}}$ activity in the triple-positive subpopulation following treatment was possibly due to a greater proliferation activity as seen in the triple-positive subpopulation (Fig. 2), all of which may lead to the production of a higher number of proliferative cells for apoptosis. It is also known that due to the cisplatin mechanism of action that binds to DNA, the activity of cisplatin is greater in highly proliferative cells since the inhibition activity of cisplatin only peaks during cellular division and mitosis (59).

In addition to the stemness and high resistance to drug treatments, high metastatic and EMT activity are also part of the hallmarks of CSCs (60). EMT would normally result in the migration of CSCs with invasive characteristics, induced by the transforming growth factor-B (TGF-B) and activation 
of hedgehog signalling pathway (61) under a hypoxic condition (62). Our findings clearly indicated that the triple-positive subpopulation exhibited significantly higher migratory phenotype on day 2 and 3 when compared to the triple-negative subpopulation. The EpCAM and CD44 target molecules, that have been reported to regulate cell migration and metastasis through the $\mathrm{Wnt} / \beta$-catenin signalling pathway (63-66), may be the key reason for cellular motility and invasion that contribute to the characteristics of CSCs, and ultimately tumour metastasis (67).

CSCs preferentially express genes relevant for stemness such as SOX2, NANOG, REX1, SSEA4 and OCT4 which have been shown to be important for human embryonic stem cell development (68). The mRNA expression of REX1 and SSEA4, were relatively higher (Fig. 9) in the triple-positive subpopulation, indicating the contribution of these pluripotent genes in the functions and maintenance of CSCs. We believed that these genes were not only important markers that can determine a pure population of CSCs, but also suitable candidate genes for targeted therapy to disrupt the regulation of CSCs for an enhanced treatment efficacy of lung cancer.

In conclusion, we revealed for the first time, that the triple-positive subpopulation derived from the A549 cell line possessed CSC characteristics, including being highly proliferative, having greater clonogenicity, ability for self-renewal through spheroid formation, being chemoresistant, and exhibiting high ALDH activity and migratory potential. To better understand the chemoresistance of this subpopulation, an in vivo drug-resistant assay can be performed to further verify the characteristics of this subpopulation. Furthermore, the gene expression analysis confirmed that the triple-positive subpopulation expressed higher pluripotent genes (REX1 and SSEA4) compared to the triple-negative subpopulation. Collectively, the present study indicated that the identified triple-positive $\left(\mathrm{EpCAM}^{+} / \mathrm{CD} 166^{+} / \mathrm{CD} 44^{+}\right)$subpopulation may be a potential candidate of CSCs for tumour samples derived from NSCLC and the population may also represent a significant group of chemoresistant cells that can be used for drug screening and chemosensitivity testing.

\section{Acknowledgments}

The authors wish to thank the Director General of Health of Malaysia for his permission to publish the present study.

\section{Funding}

The present study was supported by a grant from the Ministry of Health (MOH), Malaysia (no. JPP-IMR-16-038/NMRR-16869-30708).

\section{Availability of data and materials}

The datasets used during the present study are available from the corresponding author upon reasonable request.

\section{Authors' contributions}

KSF conceived, designed and performed the experiments. MNL performed part of the experiment and edited the manuscript. NZ, NAF and AZAR analysed the data. PB and $\mathrm{ZZ}$ provided the reagents and tools. NAS and KSF wrote the paper. BHY and PLM edited and reviewed the manuscript. All authors read and approved the manuscript and agree to be accountable for all aspects of the research in ensuring that the accuracy or integrity of any part of the work are appropriately investigated and resolved.

\section{Ethics approval and consent to participate}

All experimental protocols were approved by the Institutional Review Board, Institute for Medical Research (IMR), Malaysia and the Medical Research and Ethics Committee (MREC), Ministry of Health (MOH), Malaysia.

\section{Consent for publication}

Not applicable.

\section{Competing interests}

The authors state that they have no competing interests.

\section{References}

1. Yagui-Beltrán A and Jablons DM: A translational approach to lung cancer research. Ann Thorac Cardiovasc Surg 15: 213, 2009.

2. Okudela K, Nagahara N, Katayama A and Kitamura H: Cancer Stem Cells in Lung Cancer: Distinct Differences between Small Cell and Non-Small Cell Lung Carcinomas. Cancer Stem Cells Theories and Practice. InTech, 2011. https://www.intechopen. com/.../cancer-stem-cells-theorie. Accessed March 22, 2011.

3. Al-Hajj M, Wicha MS, Benito-Hernandez A, Morrison SJ and Clarke MF: Prospective identification of tumorigenic breast cancer cells. Proc Natl Acad Sci USA 100: 3983-3988, 2003.

4. Caramori G, Casolari P, Cavallesco GN, Giuffrè S, Adcock I and Papi A: Mechanisms involved in lung cancer development in COPD. Int J Biochem Cell Biol 43: 1030-1044, 2011.

5. Buttery RC, Rintoul RC and Sethi T: Small cell lung cancer: The importance of the extracellular matrix. Int J Biochem Cell Biol 36: 1154-1160, 2004.

6. Pei J, Lou Y, Zhong R and Han B: MMP9 activation triggered by epidermal growth factor induced FoxO1 nuclear exclusion in non-small cell lung cancer. Tumour Biol 35: 6673-6678, 2014.

7. Wang J, Li ZH, White J and Zhang LB: Lung cancer stem cells and implications for future therapeutics. Cell Biochem Biophys 69: 389-398, 2014.

8. Vermeulen L, Sprick MR, Kemper K, Stassi G and Medema JP: Cancer stem cells - old concepts, new insights. Cell Death Differ 15: 947-958, 2008.

9. Freitas DP, Teixeira CA, Santos-Silva F, Vasconcelos MH and Almeida GM: Therapy-induced enrichment of putative lung cancer stem-like cells. Int J Cancer 134: 1270-1278, 2014.

10. Dingli D and Michor F: Successful therapy must eradicate cancer stem cells. Stem Cells 24: 2603-2610, 2006.

11. Chen X, Liao R, Li D and Sun J: Induced cancer stem cells generated by radiochemotherapy and their therapeutic implications. Oncotarget 8: 17301-17312, 2017.

12. Tang Q-L, Liang Y, Xie XB, Yin JQ, Zou CY, Zhao ZQ, Shen JN and Wang J: Enrichment of osteosarcoma stem cells by chemotherapy. Chin J Cancer 30: 426-432, 2011.

13. Liloglou T, Bediaga NG, Brown BR, Field JK and Davies MP: Epigenetic biomarkers in lung cancer. Cancer Lett 342: 200-212, 2014.

14. Allan AL, Vantyghem SA, Tuck AB and Chambers AF: Tumor dormancy and cancer stem cells: Implications for the biology and treatment of breast cancer metastasis. Breast Dis 26: 87-98, 2006-2007.

15. Lobo NA, Shimono Y, Qian D and Clarke MF: The biology of cancer stem cells. Annu Rev Cell Dev Biol 23: 675-699, 2007. 
16. Velasco-Velázquez MA, Popov VM, Lisanti MP and Pestell RG: The role of breast cancer stem cells in metastasis and therapeutic implications. Am J Pathol 179: 2-11, 2011.

17. Li C, Heidt DG, Dalerba P, Burant CF, Zhang L, Adsay V, Wicha M, Clarke MF and Simeone DM: Identification of pancreatic cancer stem cells. Cancer Res 67: 1030-1037, 2007.

18. Maitland NJ and Collins AT: Prostate cancer stem cells: A new target for therapy. J Clin Oncol 26: 2862-2870, 2008.

19. Kozovska Z, Gabrisova V and Kucerova L: Colon cancer: Cancer stem cells markers, drug resistance and treatment. Biomed Pharmacother 68: 911-916, 2014.

20. Prince ME, Sivanandan R, Kaczorowski A, Wolf GT, Kaplan MJ, Dalerba P, Weissman IL, Clarke MF and Ailles LE: Identification of a subpopulation of cells with cancer stem cell properties in head and neck squamous cell carcinoma. Proc Natl Acad Sci USA 104: 973-978, 2007.

21. Wang JC and Dick JE: Cancer stem cells: Lessons from leukemia. Trends Cell Biol 15: 494-501, 2005.

22. Kristiansen G, Schlüns K, Yongwei Y, Denkert C, Dietel M and Petersen I: CD24 is an independent prognostic marker of survival in nonsmall cell lung cancer patients. Br J Cancer 88 : 231-236, 2003

23. Tirino V, Camerlingo R, Franco R, Malanga D, La Rocca A, Viglietto G, Rocco G and Pirozzi G: The role of CD133 in the identification and characterisation of tumour-initiating cells in non-small-cell lung cancer. Eur J Cardiothorac Surg 36: 446-453, 2009.

24. Leung EL-H, Fiscus RR, Tung JW, Tin VP, Cheng LC, Sihoe AD, Fink LM, Ma Y and Wong MP: Non-small cell lung cancer cells expressing CD44 are enriched for stem cell-like properties. PLoS One 5: e14062, 2010.

25. Zhang WC, Shyh-Chang N, Yang H, Rai A, Umashankar S, Ma S, Soh BS, Sun LL, Tai BC, Nga ME, et al: Glycine decarboxylase activity drives non-small cell lung cancer tumor-initiating cells and tumorigenesis. Cell 148: 259-272, 2012.

26. Lin S, Sun JG, Wu JB, Long HX, Zhu CH, Xiang T, Ma H, Zhao ZQ, Yao Q, Zhang AM, et al: Aberrant microRNAs expression in $\mathrm{CD} 133^{+} / \mathrm{CD} 326^{+}$human lung adenocarcinoma initiating cells from A549. Mol Cells 33: 277-283, 2012.

27. Laimer K, Fong D, Gastl G, Obrist P, Kloss F, Tuli T, Gassner R, Rasse M, Norer B and Spizzo G: EpCAM expression in squamous cell carcinoma of the oral cavity: Frequency and relationship to clinicopathologic features. Oral Oncol 44: 72-77, 2008.

28. Litvinov SV, van Driel W, van Rhijn CM, Bakker HA, van Krieken H, Fleuren GJ and Warnaar SO: Expression of Ep-CAM in cervical squamous epithelia correlates with an increased proliferation and the disappearance of markers for terminal differentiation. Am J Pathol 148: 865-875, 1996.

29. Munz M, Baeuerle PA and Gires O: The emerging role of EpCAM in cancer and stem cell signaling. Cancer Res 69: 5627-5629, 2009.

30. Pak MG, Shin DH, Lee $\mathrm{CH}$ and Lee MK: Significance of EpCAM and TROP2 expression in non-small cell lung cancer. World J Surg Oncol 10: 53-60, 2012

31. SkireckiT,HoserG,Kawiak J,Dziedzic D and Domagała-Kulawik J Flow cytometric analysis of CD133- and EpCAM-positive cells in the peripheral blood of patients with lung cancer. Arch Immunol Ther Exp (Warsz) 62: 67-75, 2014

32. Tachezy M, Zander H, Wolters-Eisfeld G, Müller J, Wicklein D, Gebauer F, Izbicki JR and Bockhorn M: Activated leukocyte cell adhesion molecule (CD166): An 'inert' cancer stem cell marker for non-small cell lung cancer? Stem Cells 32 1429-1436, 2014.

33. de Beça FF, Caetano P, Gerhard R, Alvarenga CA, Gomes M, Paredes J and Schmitt F: Cancer stem cells markers CD44, CD24 and ALDH1 in breast cancer special histological types. J Clin Pathol 66: 187-191, 2013.

34. Jing F, Kim HJ, Kim CH, Kim YJ, Lee JH and Kim HR: Colon cancer stem cell markers CD44 and CD133 in patients with colorectal cancer and synchronous hepatic metastases. Int J Oncol 46: 1582-1588, 2015

35. Takaishi S, Okumura T, Tu S, Wang SS, Shibata W, Vigneshwaran R, Gordon SA, Shimada Y and Wang TC: Identification of gastric cancer stem cells using the cell surface marker CD44. Stem Cells 27: 1006-1020, 2009.

36. Su J, Wu S, Wu H, Li L and Guo T: CD44 is functionally crucial for driving lung cancer stem cells metastasis through Wnt/ $\beta$-catenin-FoxM1-Twist signaling. Mol Carcinog 55: 1962-1973, 2016
37. Barrandon Y and Green H: Cell size as a determinant of the clone-forming ability of human keratinocytes. Proc Natl Acad Sci USA 82: 5390-5394, 1985.

38. Zakaria N, Yusoff NM, Zakaria Z, Lim MN, Baharuddin PJ, Fakiruddin KS and Yahaya B: Human non-small cell lung cancer expresses putative cancer stem cell markers and exhibits the transcriptomic profile of multipotent cells. BMC Cancer 15: 84, 2015.

39. Shi Y, Fu X, Hua Y, Han Y, Lu Y and Wang J: The side population in human lung cancer cell line NCI-H460 is enriched in stem-like cancer cells. PLoS One 7: e33358, 2012.

40. Wang P, Gao Q, Suo Z, Munthe E, Solberg S, Ma L, Wang M, Westerdaal NA, Kvalheim G and Gaudernack G: Identification and characterization of cells with cancer stem cell properties in human primary lung cancer cell lines. PLoS One 8: e57020, 2013.

41. Levin TG, Powell AE, Davies PS, Silk AD, Dismuke AD Anderson EC, Swain JR and Wong MH: Characterization of the intestinal cancer stem cell marker CD166 in the human and mouse gastrointestinal tract. Gastroenterology 139: 2072-2082. e5, 2010.

42. Li W, Ma H, Zhang J, Zhu L, Wang C and Yang Y: Unraveling the roles of CD44/CD24 and ALDH1 as cancer stem cell markers in tumorigenesis and metastasis. Sci Rep 7: 13856, 2017.

43. Bahnassy AA, Fawzy M, El-Wakil M, Zekri AR, Abdel-Sayed A and Sheta M: Aberrant expression of cancer stem cell markers (CD44, CD90, and CD133) contributes to disease progression and reduced survival in hepatoblastoma patients: 4-year survival data. Transl Res 165: 396-406, 2015.

44. Zhang $\mathrm{H}$, Lin XG, Hua P, Wang M, Ao X, Xiong LH, Wu C and Guo JJ: The study of the tumor stem cell properties of CD133+ $\mathrm{CD} 44^{+}$cells in the human lung adenocarcinoma cell line A549. Cell Mol Biol (Noisy-le-grand) 56: Suppl: OL1350-8, 2010.

45. Barrandon Y and Green H: Three clonal types of keratinocyte with different capacities for multiplication. Proc Natl Acad Sci USA 84: 2302-2306, 1987.

46. Yan W, Chen Y, Yao Y, Zhang $\mathrm{H}$ and Wang T: Increased invasion and tumorigenicity capacity of $\mathrm{CD} 44^{+} / \mathrm{CD} 24^{-}$breast cancer MCF7 cells in vitro and in nude mice. Cancer Cell Int 13: 62, 2013.

47. Reya T, Morrison SJ, Clarke MF and Weissman IL: Stem cells, cancer, and cancer stem cells. Nature 414: 105-111, 2001.

48. Dean M, Fojo T and Bates S: Tumour stem cells and drug resistance. Nat Rev Cancer 5: 275-284, 2005.

49. Huang C-P, Tsai MF, Chang TH, Tang WC, Chen SY, Lai HH, Lin TY, Yang JC, Yang PC, Shih JY, et al: ALDH-positive lung cancer stem cells confer resistance to epidermal growth factor receptor tyrosine kinase inhibitors. Cancer Lett 328: 144-151, 2013.

50. Izumiya M, Kabashima A, Higuchi H, Igarashi T, Sakai G, Iizuka H, Nakamura S, Adachi M, Hamamoto Y, Funakoshi S, et al: Chemoresistance is associated with cancer stem cell-like properties and epithelial-to-mesenchymal transition in pancreatic cancer cells. Anticancer Res 32: 3847-3853, 2012.

51. Todaro M, Alea MP, Di Stefano AB, Cammareri P, Vermeulen L, Iovino F, Tripodo C, Russo A, Gulotta G, Medema JP, et al: Colon cancer stem cells dictate tumor growth and resist cell death by production of interleukin-4. Cell Stem Cell 1: 389-402, 2007.

52. Chen Y-C, Chen YW, Hsu HS, Tseng LM, Huang PI, Lu KH, Chen DT, Tai LK, Yung MC, Chang SC, et al: Aldehyde dehydrogenase 1 is a putative marker for cancer stem cells in head and neck squamous cancer. Biochem Biophys Res Commun 385: 307-313, 2009.

53. Huang EH, Hynes MJ, Zhang T, Ginestier C, Dontu G, Appelman H, Fields JZ, Wicha MS and Boman BM: Aldehyde dehydrogenase 1 is a marker for normal and malignant human colonic stem cells (SC) and tracks SC overpopulation during colon tumorigenesis. Cancer Res 69: 3382-3389, 2009.

54. Charafe-Jauffret E, Ginestier C, Iovino F, Tarpin C, Diebel M, Esterni B, Houvenaeghel G, Extra JM, Bertucci F, Jacquemier J, et al: Aldehyde dehydrogenase 1-positive cancer stem cells mediate metastasis and poor clinical outcome in inflammatory breast cancer. Clin Cancer Res 16: 45-55, 2010.

55. Jiang F, Qiu Q, Khanna A, Todd NW, Deepak J, Xing L, Wang H, Liu Z, Su Y, Stass SA, et al: Aldehyde dehydrogenase 1 is a tumor stem cell-associated marker in lung cancer. Mol Cancer Res 7: 330-338, 2009.

56. Tanei T, Morimoto K, Shimazu K, Kim SJ, Tanji Y, Taguchi T, Tamaki Y and Noguchi S: Association of breast cancer stem cells identified by aldehyde dehydrogenase 1 expression with resistance to sequential Paclitaxel and epirubicin-based chemotherapy for breast cancers. Clin Cancer Res 15: 4234-4241, 2009. 
57. Bouchier-Hayes L, Muñoz-Pinedo C, Connell S and Green DR Measuring apoptosis at the single cell level. Methods 44: 222-228, 2008

58. Ma D, Tremblay P, Mahngar K, Akbari-Asl P, Collins J, Hudlicky T and Pandey S: Induction of apoptosis and autophagy in human pancreatic cancer cells by a novel synthetic C-1 analogue of 7-deoxypancratistatin. Am J Biomed Sci 3: 278-291, 2011.

59. Dasari S and Tchounwou PB: Cisplatin in cancer therapy: Molecular mechanisms of action. Eur J Pharmacol 740: 364-378, 2014.

60. Wang X, Zhu Y, Ma Y, Wang J, Zhang F, Xia Q and Fu D: The role of cancer stem cells in cancer metastasis: New perspective and progress. Cancer Epidemiol 37: 60-63, 2013.

61. Wang F, Ma L, Zhang Z, Liu X, Gao H, Zhuang Y, Yang P, Kornmann M, Tian X and Yang Y: Hedgehog signaling regulates epithelial-mesenchymal transition in pancreatic cancer stem-like cells. J Cancer 7: 408-417, 2016.

62. Singh A and Settleman J: EMT, cancer stem cells and drug resistance: An emerging axis of evil in the war on cancer Oncogene 29: 4741-4751, 2010.

63. Ni J, Cozzi P, Hao J, Beretov J, Chang L, Duan W, Shigdar S, Delprado W, Graham P, Bucci J, et al: Epithelial cell adhesion molecule (EpCAM) is associated with prostate cancer metastasis and chemo/radioresistance via the PI3K/Akt/mTOR signaling pathway. Int J Biochem Cell Biol 45: 2736-2748, 2013.
64. Patriarca C, Macchi RM, Marschner AK and Mellstedt $\mathrm{H}$ : Epithelial cell adhesion molecule expression (CD326) in cancer: A short review. Cancer Treat Rev 38: 68-75, 2012.

65. Visvader JE and Lindeman GJ: Cancer stem cells in solid tumours: Accumulating evidence and unresolved questions. Nat Rev Cancer 8: 755-768, 2008

66. Wielenga VJ, Smits R, Korinek V, Smit L, Kielman M, Fodde R, Clevers H and Pals ST: Expression of CD44 in Apc and Tcf mutant mice implies regulation by the WNT pathway. Am J Pathol 154: 515-523, 1999.

67. Hou J-M, Krebs M, Ward T, Sloane R, Priest L, Hughes A, Clack G, Ranson M, Blackhall F and Dive C: Circulating tumor cells as a window on metastasis biology in lung cancer. Am J Pathol 178: 989-996, 2011.

68. Mizrak SC, Chikhovskaya JV, Sadri-Ardekani H, van Daalen S, Korver CM, Hovingh SE, Roepers-Gajadien HL, Raya A, Fluiter K, de Reijke TM, et al: Embryonic stem cell-like cells derived from adult human testis. Hum Reprod 25: 158-167, 2010.

c) (7) $(-)$ This work is licensed under a Creative Commons Attribution-NonCommercial-NoDerivatives 4.0 International (CC BY-NC-ND 4.0) License. 